\title{
Performance of asmetric structures reviewed with based plastic design performance (case study of application on building in Pekan Baru)
}

\author{
Jati Sunaryati ${ }^{*}$, Nidiasari $^{1}$, and Alfadian ${ }^{1}$ \\ ${ }^{1}$ Civil Engineering Departement, Universitas Andalas, Kampus Limau Manis, Padang, Indonesia
}

\begin{abstract}
Performance-Based Plastic Design (PBPD) is a structural analysis that can be used to review structural performance. This method is increasingly popular to be used in the earthquake-prone area. This method is based on energy method that can be applied to steel or concrete structures. Meanwhile, Indonesia has already SNI 1726:2102 to be used as a guide in designing the thrust load to review the level of structural performance. Both of these things need to be used as a reference in areas that were initially considered safe from the earthquake but based on the development of earthquake micro zonation maps, it is very possible to become potential areas that also become earthquake regions. For this reason, the case of the structure that was built in the Pekanbaru area was taken. From the analyses of structural behavior, the structure that applied PBPD has greater displacement than the structures that apply the thrust load of SNI 1726: 2012. The percentage of displacement that occurred was $8-37 \%$. Based on performance analysis, the structures according to PBPD shows a better level of performance to the application of SNI 1726: 2012 thrust load.
\end{abstract}

\section{Introduction}

The Government of Indonesia, through the Indonesian National Standardization Agency together with national earthquake experts, has set a standard in the planning of buildings that are earthquake-safe. This standard is contained in the Indonesian National Standard SNI 031726-2012 concerning Procedures for Planning Earthquake Resilience for Buildings. In this regulation, the planned earthquake is designated as an earthquake with the possibility of exceeding its magnitude over the life span of a 50 -year building structure of 2 percent. The maximum earthquake is an earthquake with a 2500 year return period. The targeted risks considered are MCER Maximum Considered Earthquake Targeted Risk-taking into (1) Hazard earthquake (damage hazard - MCE), (2) probabilistic MCER (3) deterministic MCER (fault) (4) Risk coefficient (4) Cr) or Collapse Fragility (Vulnerability): probability of structure collapse with earthquake risk $=2 \%$ of building age 50 years.

While the energy concept used in the PerformanceBased Plastic Design (PBPD) method is very similar to the basic approach used by Housner (1956), Housner uses the difference between the energy inputted with elastic tension energy to obtain the plastic energy absorbed by the structure for the design of melting plan.

The PBPD method uses the selection of drift targets and yield mechanisms as base performance constraints. Both of these limits have a direct effect on the level and distribution of building damage. The basic earthquake shear force of the plan for the specified hazard level is calculated by equalizing the amount of load that works to push the structure monotonically to the target drift limit used for the distribution of new lateral loads from the plan load

PBPD uses lateral force calculation and refers to the energy balance method so that the value of the energy balance modification factor is obtained.

\subsection{Purposes}

The purpose of this paper is to analyze the structure's performance if it is subject to earthquake loads based on SNI 1726: 2012 and Performance-Based Plastic Design (PBPD). The performance reviewed is the process of plastic joints, structural displacement, displacement ductility and drift ratio of the structure.

\subsection{Data structure}

The technical data of the four-story office building reinforced concrete structure used are as follows :

Concrete strength, $\mathrm{f}_{\mathrm{c}}{ }^{\prime}=29 \mathrm{MPa}$,

Reinforcement steel strength, $\mathrm{f}_{\mathrm{y}}=400 \mathrm{MPa}$,

Building height $=14.5 \mathrm{~m}$.

The Indonesian Earthquake Hazard Map used is the Map of 2010 and the Indonesian Spectra of 2010 contained in SNI 1762: 2012 on the Procedures for Earthquake Resilience Planning for Buildings and Non-

* Corresponding author: jati@eng.unand.ac.id 
Buildings. The Performance-Based Plastic Design method is based on studies by researchers Shih-Ho Chao and C. Goel (2005)

\section{Loads on structure}

The dead load used in the calculation is the own weight of building materials and building components taken by the Indonesian Load Regulations for Buildings 1983 as well as the Indonesian Loading Standards for Buildings (SNI 1727-1989). For self-weight, the structure is automatically calculated in the structural analysis program used.

\subsection{Response Spectrum}

The earthquake load used is for office buildings in the city of Pekanbaru. This dynamic load is in the form of a spectrum response contained in SNI 1726: 2012 with soft soil conditions, as shown in the following figure.

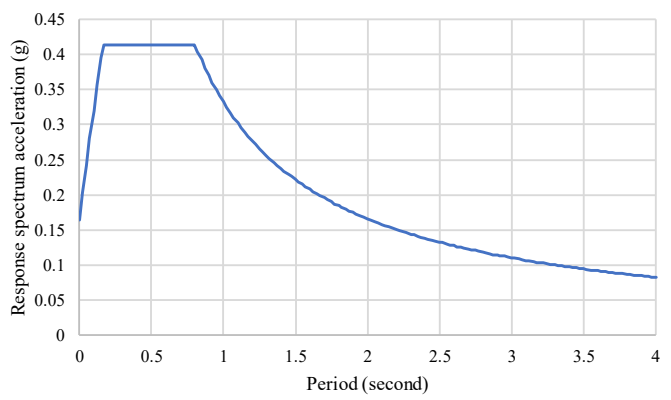

Fig. 1. The spectrum response of Pekanbaru City according to SNI 1726:2012

\subsection{Earthquake load base on PBPD}

Earthquake Shear Force used in Performance-Based Plastic Design (PBPD) is to use the following equation.

\subsubsection{Plastic rotation ( $\left.\theta_{u}\right)$.}

The value of the target drift $\left(\theta_{u}\right)$ is planned with a value of $2 \%$, and the value of the yield drift ratio $\left(\theta_{y}\right)$ for reinforced concrete structures is $0.5 \%$, then a value of $1.5 \%$ is obtained.

\subsubsection{Ductility $\left(\mu_{s}\right)$}

The ductility is $\mu_{s}=\frac{\theta_{u}}{\theta_{y}}$

so the value of ductility is 4

\subsubsection{A changing factor for the energy balance equation $(\gamma)$}

$\gamma=\frac{2 \mu_{s}-1}{R_{\mu}^{2}}$
Value of $R_{\mu l}$ is 2,65 . Thus the value of the change factor for the energy balance equation is $(\gamma)=0,997$

\subsubsection{Shear force comparison factor $\left(\beta_{i}\right)$}

$\beta_{i}=\left(\frac{\sum_{i=1}^{n} w_{i} h_{i}}{w_{n} h_{n}}\right)^{0.75 . T^{-0.2}}$

The value of period is $(\mathrm{T})=0,517$ second, where $w_{n} h_{n}$ is the multiplication between the weight of the structure and the height of the structure on the top floor, so $\beta_{i}$ the values for each floor on the second floor to the 5 th floor are $3.3 ; 2.8 ; 2.0$ and 1 .

\subsubsection{Plan shear force parameter $(\propto)$}

$$
\alpha-\left(\sum_{i=1}^{n}\left(\beta_{i}-\beta_{i+1}\right) h_{i}\right)\left(\frac{w_{n} h_{n}}{\sum_{j=1}^{n} w_{i} h_{i}}\right)^{0.75 T^{-0.2}}\left(\frac{\theta_{p} 8 \pi^{2}}{T^{2} g}\right)
$$

The value of $(\alpha)=4,598$

\subsubsection{The basic shear force of earthquake plan (V)}

$\frac{V}{W}=\frac{-\alpha \pm \sqrt{\alpha^{2}+4 \gamma C_{e}^{2}}}{2}$

Value of the basic shear force of earthquake plan $\mathrm{V}=$ $200848,74 \mathrm{~kg}$

\subsubsection{Lateral load on top roof $\left(F_{n}\right)$}

$$
F_{n}=V\left(\frac{w_{n} h_{n}}{\sum_{j=1}^{n} w_{i} h_{i}}\right)^{0.75 r^{-0 . z}}
$$

The value of $\left(F_{n}\right)=488319,821 \mathrm{~kg}$

\subsubsection{Laeral load per floor $i\left(F_{i}\right)$}

$F_{i}=\left(\beta_{i}-\beta_{i+1}\right) F_{n}$

(while $\mathrm{i}=\mathrm{n}$, so $\beta_{i+1}=0$ )

Based on the loading according to SNI 1726: 2012 and the PBPD, then in Table 1 can be seen the lateral force value of each floor.

Tabel 1. Lateral force of each story $\left(F_{i}\right)$

\begin{tabular}{|c|c|c|}
\hline Storey & Fi (SNI 1726:2012), (N) & Fi (PBPD), (N) \\
\hline Rooftop & 72236.855 & 49672.001 \\
\hline 4th floor & 90383.020 & 49796.213 \\
\hline 3rd floor & 82945.425 & 42062.805 \\
\hline 2nd floor & 46524.427 & 22652.992 \\
\hline
\end{tabular}




\section{Analyses dan discussion}

\subsection{Structural Model}

The structure design is carried out following the Procedures for Calculating Concrete Structures for Buildings (SNI 03-2847-2002). The structure is modeled as shown below

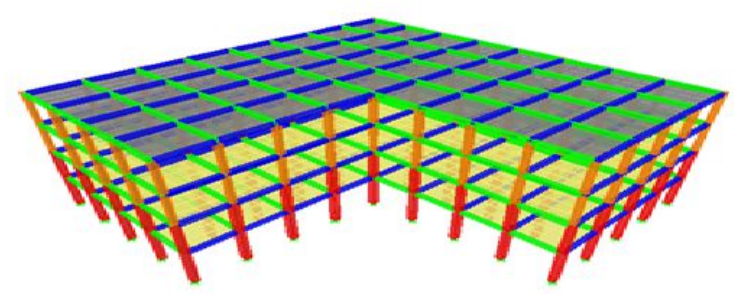

Fig 2. 3D model of the structure

\subsection{Location of displacement observation}

In analyzing the large differences in the value of displacement in the beams of the two structures, it is first necessary to determine the locations of displacement observation points that can be seen in Fig. 3 .

\subsection{Plastic hinges}

Based on the results of pushover analysis on structures that apply SNI 1726.2012, it is known that the structure begins to experience the condition of the plastic joints in the 12th step, and then experiences the first melt in the 34 th step with a displacement of $74.9895 \mathrm{~mm}$ and then collapses in the 80th step with displacement of $171.5469 \mathrm{~mm}$ with the actual structural ductility value obtained at 2.29. Based on the results of pushover analysis, it is known that the structure begins to experience the condition of the plastic joints of the $3 \mathrm{rd}$ step (Fig.4.), and then experiences the first melt in the 10th step with a displacement of $70.9935 \mathrm{~mm}$ and then collapses in the 24th step (Fig. 5) with a displacement of $185.4619 \mathrm{~mm}$. The actual structural ductility value obtained was 2.612 .

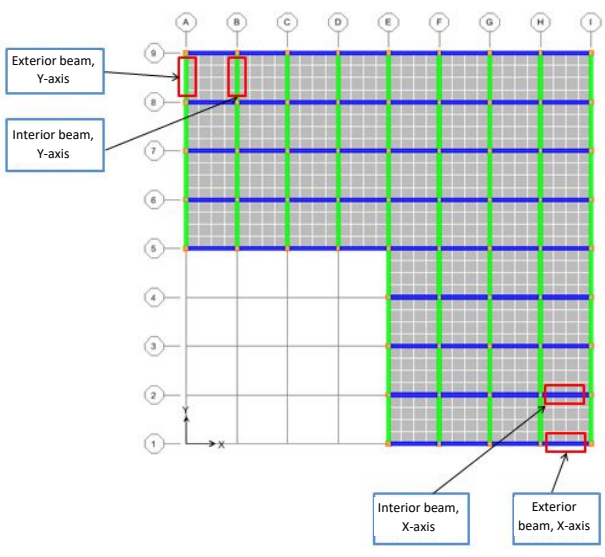

Fig.3. Location of displacement observation on beams

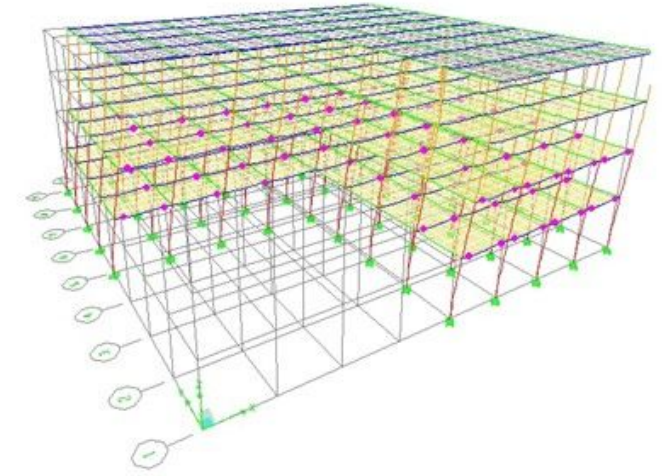

Fig.4. The first plastic hinge is based on Performance Based Plastic Design (PBPD) in step 3

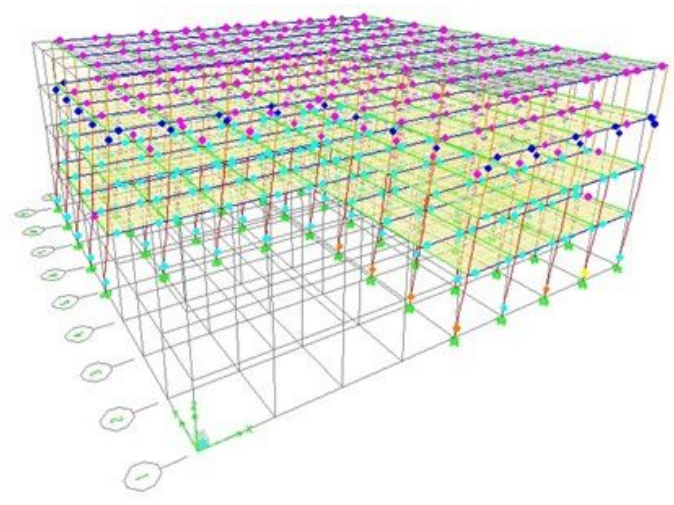

Fig.5. When a collapse occurs based on PBPD in step 24

\subsection{Displacements of structure}

The structural displacement that occurs according to the point of view is as illustrated in Fig. 6 to Fig. 9 below.

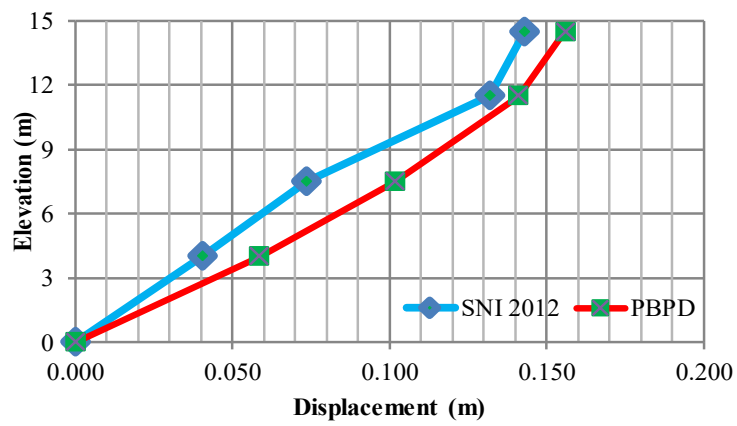

Fig. 6. Graph of total displacement (x) on X beam exterior

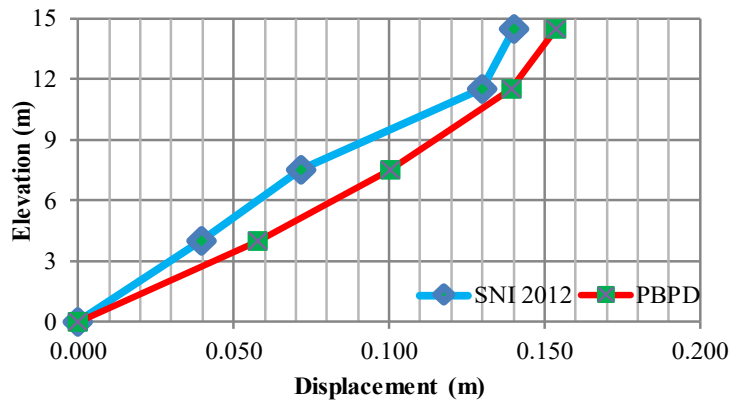

Fig. 7. Graph of total displacement (x) on X beam interior 


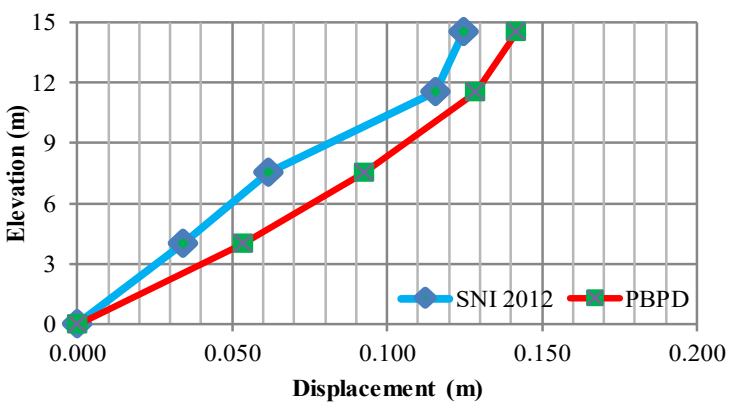

Fig. 8. Graph of total displacement $(\mathrm{x})$ on $\mathrm{Y}$ beam exterior

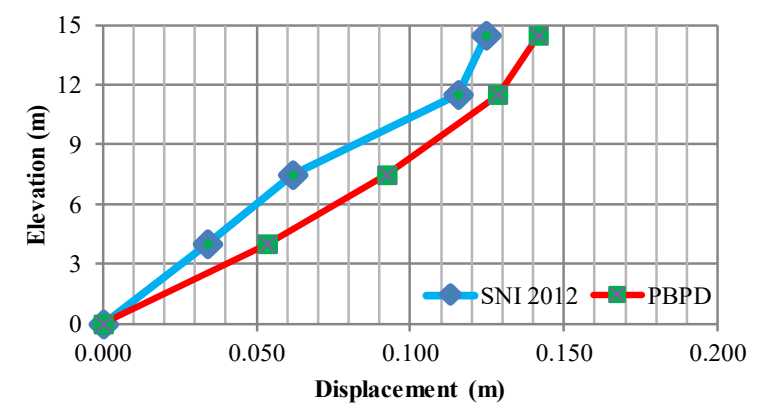

Fig. 9. Graph of total displacement (x) on Y beam interior

Based on the graph above, it appears that the displacement that occurs in the structure caused by earthquake loads based on Performance-Based Plastic Design (PBPD) is greater than SNI 1726: 2012. The percentage of the increase occurred at $8 \%-37 \%$ at each review point.

\subsection{Drift Ratio}

At the beginning of planning, for structures analyzed using the method of Performance-Based Plastic Design (PBPD) it was determined that the value of the Yield Drift ratio was $0.5 \%$ (table 2.2). After a Pushover analysis, it is found that the Yield Drift Ratio value obtained is close to the planned Drift Ratio value of $0.49 \%$. For structures with SNI 1726: 2012 analysis the Yield Drift Ratio value is obtained after a pushover analysis with a Yield Drift Ratio value of 0,00037 or $0.037 \%$

\section{CONCLUSION}

From the analysis of structural responses that have been carried out, it can be concluded as follows: (1) Lateral force for modeling based on Performance-Based Plastic Design (PBPD) is greater than modeling based on SNI 1726: 201 (2) Actual ductility value for structures designed based on Performance-Based Plastic Design (PBPD) is higher compared to structures designed based on SNI 1726: 2012 (3) Percentage of increase in displacement (displacement) in building structures between $8-37 \%$

\section{References}

1. Luthfi, Ghazian. Studi Perbandingan Perilaku Struktur Beton Dengan Lavout Bangunam Berbentuk Yang Didisain Berc arkan SNI 031726-2002 dan SNI 1726-2012(Studi Kasus Kota Pekanbaru). Tugas Akhir Teknik Sipil Universitas Andalas. Padang (2014).

2. Titono, Michael. 2010. Analisa Ketahanan Gempa Dalam Rangka Konservasi Bangunan Bersejarah, Studi Kasus: Gedung X. Universitas Indonesia (2010)

3. Chao, Shih-Ho dan Goel, C. Performance -Based Seismic Design Of EBF Using Target Drift and Yield Mechanism As Performance Criteria. Department of Civil and Environmental Engineering The University of Michigan. Michigan (2005)

4. Cheng Liao, Wen. 2010. Performance -Based Plastic Design Of Earthquake Resistant Reinforced Concrete Moment Frames. A Dissertation Submitted In Partial Fulfillment of The Requirements for The Degree of Doctor of Philosophy (Civil Engineering) in The University of Michigan. Michigan (2010)

5. Badan Standarisasi Nasional. Standar Perencanaan Ketahanan Gempa Untuk Struktur Bangunan Gedung dan Non Gedung SNI 1726-2012.Jakarta (2012)

6. Dewobroto, Wiryanto. Evaluasi Kinerja Struktur Baja Tahan Gempa dengan Analisa Puhsover. Civil Engineering National Conference: Suistainability Construction \& Structural Engineering. Semarang (2005) 